\title{
Molecular Cloning of WHI2, a Gene Involved in the Regulation of Cell Proliferation in Saccharomyces cerevisiae
}

\author{
By D. J. SAUL† AND P. E. SUDBERY* \\ Department of Genetics, University of Sheffield, Sheffield S10 2TN, UK
}

(Received 5 November 1984 ; revised 31 January 1985)

The WHI2 gene of Saccharomyces cerevisiae plays a key role in co-ordinating cell proliferation and nutrient availability. A $2.6 \mathrm{~kb}$ yeast DNA sequence has been cloned which fully suppresses the whi 2 mutation. Integration of this sequence to demonstrate that the structural gene itself had been cloned proved difficult. Integration occurred only rarely and only at the LEU 2 locus which was also present on the integrating plasmid. To circumvent these difficulties an adjacent sequence, present on the original isolate from the gene library, was subcloned onto the integrating vector YIp5, after which directed integration proved straightforward. The integrated sequence was closely linked to $W H I 2$, confirming that the structural gene had been cloned. A chromosomal restriction map of the $W H I 2$ region is presented; no gross changes were observed in the region as cells entered stationary phase.

\section{INTRODUCTION}

whi 2 is a mutation of Saccharomyces cerevisiae which disturbs the normal coordination of cell proliferation with nutrient availability (Sudbery et al., 1980). Batch cultures of wild-type cells grown on complex YEPD medium cease proliferating when the carbon source becomes limiting in stationary phase, cell cycle arrest occurs in Gl and cells accumulate in the unbudded state (Hartwell, 1974). In contrast, whi 2 cells continue dividing as the carbon supply becomes exhausted, the consequent division without cell growth results in cells becoming smaller and a higher cell density is eventually attained. Cell proliferation ceases only when no more energy is available for essential functions, and then arrest occurs randomly in the cell cycle (Sudbery et al., 1980).

As wild-type cells enter stationary phase a series of concerted changes occur in cell physiology, giving rise to a number of differences in the properties of stationary phase cells compared to exponentially growing cells. Thus stationary phase cells are more resistant to a $52{ }^{\circ} \mathrm{C}$ heat shock (Parry et al., 1976; Schenberg-Frascino \& Moustacchi, 1971), to nystatin treatment (Snow, 1966) and to spheroplast formation (Deutch \& Parry, 1973). They are phase bright compared to the phase dark appearance of exponentially growing cells, and contain a higher proportion of glycogen and trehalose accumulated in the last few rounds of division before arrest (Lillie \& Pringle, 1980). In conditions of carbon limitation, whi2 cells retain the properties of exponentially growing cells and fail to show any of the changes shown by wild-type cells described above (Sudbery et al., 1980; Saul et al., 1985).

In continuous culture cell size of wild-type cells is proportional to growth rate at fast growth rates but becomes independent of growth rate at slower growth rates (Lorincz \& Carter, 1979; Johnston et al., 1979). whi2 cells are indistinguishable from wild-type cells at fast growth rates but continue to decrease in size at slower growth rates (E. F. Walton \& B. L. A. Carter, personal communication). A final difference between whi 2 and wild-type cells is that whi 2 cells are able to sustain a much faster rate of growth on poor carbon sources such as acetate, glycerol and ethanol (E. F. Walton \& B. L. A. Carter, personal communication).

$\dagger$ Present address: Department of Cell Biology, University of Auckland, New Zealand. 
The $W H I 2$ gene thus plays a crucial role either in the cell's perception of the nutritional status of the environment, or its ability to respond in terms of cell proliferation, cell size and growth rate. In order to study its role at a molecular level we report here on the molecular cloning of the $W H I 2$ gene.

\section{METHODS}

Culture media and conditions. Complex YEPD medium, supplemented synthetic medium, presporulation and sporulation media, and culture conditions and methods for genetic analysis were all as described by Sherman et al. (1974). Bacterial culture media and conditions were as described by Maniatis et al. (1982).

Strains. The Escherichia coli strains used were as follows.

JA221 (recAl leuB6 trpE5 hsdR hsd $M^{+}$lac Y C600) from J. Beggs (University of Edinburgh, UK).

ED8654 (supE supF hsdR) from N. Murray (Dept of Molecular Biology, University of Edinburgh, UK).

HB101 was from H. B. Boyer (University of California Medical Center, San Francisco, CA 94122, USA).

The Saccharomyces cerevisiae strains used were as follows.

X4003-5B (a leu2 adel his 4 met 2 ura 3 trp5) from the Yeast Stock Center, Berkeley, Calif., USA.

M11-30, a Met- derivative of M11 ( $\alpha$ whi2 his4; Sudbery et al., 1980) recovered after EMS mutagenesis.

Iso 34 ( $\alpha$ whi2 his 4 trp 5 leu2). This strain is $87.5 \%$ isogenic with X4003-5B. It was constructed by crossing M1130 with X4003-5B. The resulting diploid was sporulated and progeny haploid clones recovered after ether treatment (Dawes \& Hardie, 1974). leu 2 whi $2 \mathrm{Met}^{+}$progeny were crossed with X4003-5B as above and the progeny crossed a third time to $\mathrm{X} 4003-5 \mathrm{~B}$. The progeny of the final cross were screened for transformability. Iso 34 transformed as efficiently as the parent X $4003-5 B$.

Iso 38 ( $\alpha$ whi2 leu 2 trp 5 ura 3 ade 1 ). This strain is a sister clone of Iso 34.

Expression of the whi2 phenotype and cell size measurement. Cells from a fresh YEPD plate culture were inoculated in $2.5 \mathrm{ml}$ YEPD in a $25 \mathrm{ml}$ conical flask and shaken at $28^{\circ} \mathrm{C}$ for $48 \mathrm{~h}$. After this time $W H I 2$ cells had reached stationary phase and were phase bright and unbudded when examined under a phase contrast microscope at $400 \times$ magnification. whi2 cells were phase dark, budded and smaller (see Figs 1 and 2). The large ratio of flask size to culture volume was important for clear expression of the phenotype. Cell size measurements of $\mathrm{WHI}^{+}$and whi2 were made with a Coulter counter model ZB1, C1000 analyser and slave recorder. Latex beads $(4.63 \mu \mathrm{m}$ diameter) were used as size standards. In our hands this method always gives slightly smaller cell volumes than measurements made from photographs (Sudbery et al., 1980).

DNA preparation. Total yeast DNA was prepared according to the method of Hicks (1982) except that $250 \mathrm{ml}$ of culture was used. The rest of the procedure was scaled up accordingly. Such DNA preparations are referred to as 'rapid' in the text. In some cases, further purification was carried out by banding on caesium chloride/ethidium bromide gradients. Such DNA is referred to as 'purified' in the text.

Large and small plasmid preparations were made by the alkaline extraction method of Birnboim \& Doly (1979), as modified and described by Maniatis et al. (1982). Large scale plasmid preparations were further purified by banding in caesium chloride/ethidium bromide gradients (Maniatis et al., 1982).

Plasmid was extracted from yeast cells by a method modified from that of Birnboim \& Doly (1979). Plasmid bearing strains of $S$. cerevisiae were grown under selective conditions in $20 \mathrm{ml}$ synthetic medium to $\mathrm{OD}_{600} 0 \cdot 5$. The cells were then centrifuged at 6000 r.p.m. $(3000 \mathrm{~g})$, resuspended in $20 \mathrm{ml} 1 \mathrm{M}$-sorbitol, $20 \mathrm{mM}-\mathrm{K}_{2} \mathrm{HPO}_{4} / \mathrm{KH}_{2} \mathrm{PO}_{4}$ pH 7.5, $20 \mathrm{~mm}$-EDTA and stood on ice for $5 \mathrm{~min}$. The cells were sedimented and resuspended in $0.2 \mathrm{ml} 1 \mathrm{M}$ sorbitol, $10 \mathrm{~mm}$-Tris/HCI pH 7.5, $1 \mathrm{mm-dithiothreitol,} 3 \mathrm{mg}$ Zymolyase $5000 \mathrm{ml}^{-1}$ (Miles), and incubated at $30^{\circ} \mathrm{C}$ for $1 \mathrm{~h}$. To the mix was added $0.8 \mathrm{ml}$ sterile distilled water, $2 \mathrm{ml} 0.2 \mathrm{M}-\mathrm{NaOH}$, and $1 \%(\mathrm{w} / \mathrm{v}$ ) SDS, and the cells were permitted to lyse at room temperature for $1 \mathrm{~h}$. Then $1.5 \mathrm{ml} 3 \mathrm{M}$-sodium acetate adjusted to $\mathrm{pH} 5.8$ with acetic acid was added and after a further incubation at room temperature for $60 \mathrm{~min}$ the lysate was centrifuged for $15 \mathrm{~min}$ at $12000 \mathrm{r}$.p.m. $(12000 \mathrm{~g})$. The DNA was then recovered from the supernatant by ethanol precipitation.

Construction of the gene library. pJDB207 was digested with BamHI, treated with calf intestinal alkaline phosphatases and repurified by phenol extraction. It was then ligated to yeast total DNA which had been partially digested with Sau3A. E. coli ED8654 cells were transformed to ampicillin resistance with the ligated mixture; $4 \times$ $10^{4}$ transformants were obtained, $98 \%$ of which were tetracycline sensitive. Plasmid was extracted and purified from a sample of pooled colonies.

Transformation. Yeast transformation was done as described by Beggs (1978). E. coli was transformed by the method of Lederberg \& Cohen (1974).

Restriction digests, agarose gel electrophoresis and Southern hybridization. Restriction enzymes were from Boehringer Mannheim, Bethesda Research Laboratories and Sigma. They were used according to the vendors' instructions. Agarose gel electrophoresis was on horizontal gels (Tris/acetate buffer and $0.8-1 \cdot 2 \%$ agarose). Southern blotting (Southern, 1975), hybridization and autoradiography were as described in the Basic Cloning Techniques Course Manual (Leicester University, 1981). All post hybridization washes were in $0 \cdot 1 \times \mathrm{SSC}$ at $65^{\circ} \mathrm{C}$ $(1 \times \mathrm{SSC}$ is $0.15 \mathrm{M}-\mathrm{NaCl}, 0.015 \mathrm{M}$-trisodium citrate, $\mathrm{pH} 7 \cdot 0)$. 
Nick translation. Hybridization probes were prepared with $\alpha^{-32} \mathrm{P}$-labelled dCTP and a nick translation kit, both purchased from Amersham and used according to the vendor's instructions. Typically DNA was labelled to a specific activity of $5 \times 10^{7}$ c.p.m. $\mu \mathrm{g}^{-1}$, of which $10^{7}$ c.p.m. would be used in a $20 \mathrm{ml}$ hybridization volume.

\section{RESULTS AND DISCUSSION \\ Construction of a gene library}

A gene library was constructed from wild-type DNA in the BamHI site of pJDB207 (Beggs, 1981), a $2 \mu \mathrm{m}$ based vector containing the yeast $L E U 2$ gene. Total DNA from X2180-1 A was partially digested with Sau3A so that the average fragment size was $8-20 \mathrm{~kb}$, as described in Methods. These fragments were ligated to BamHI digested, alkaline phosphatase treated pJDB207 and the mixture used to transform E. coli ED8654 cells to Ampr $; 40000$ colonies were recovered, $98 \%$ of which were $\mathrm{Tet}^{\mathrm{s}}$ due to the insertional inactivation of the tetracycline resistance gene of pJDB207. Plasmids from 24 clones were characterized. The average insert size was $5 \mathrm{~kb}$.

\section{Construction of a high transforming whi2 recipient}

The whi 2 mutation was originally isolated in strain M11. In our hands at least, this strain transformed very inefficiently. We also needed a leu 2 recipient, so we crossed the whi 2 mutation into a high transforming leu 2 background. In our hands the strain X4003-5B transformed very efficiently so we crossed M11-30 (see Methods) to X4003-5B and recovered leu 2 whi2 segregants, but these still transformed inefficiently. Two further backcrosses to X4003-5B were necessary before good transforming strains were obtained. One such strain was selected as a recipient. This strain, designated Iso 34 , is $87.5 \%$ isogenic to X4003-5B and has the genotype $\alpha$ whi2 leu2 his4 trp5.

\section{Recovery of $\mathrm{Whi}^{+}$transformants}

The gene library constructed as described above was used to transform Iso 34 cells to $\mathrm{Leu}^{+}$. Transformation occurred inefficiently, at a rate of only $10^{2}$ transformants $\left(\mu \mathrm{g}\right.$ DNA) ${ }^{-1}$. This low rate of transformation was characteristic of the library. A total of $6000 \mathrm{Leu}^{+}$colonies were obtained; these were harvested as described in Methods and the colonies from each plate inoculated into $2.5 \mathrm{ml}$ YEPD and allowed to grow to stationary phase. The stationary phase culture was then subjected to a $50{ }^{\circ} \mathrm{C}$ heat shock for $4 \mathrm{~h}$ in order to kill $\mathrm{Whi}^{-}$cells. The culture was diluted and plated on YEPD. The survival rate was $10^{-3}$. Surviving colonies were picked separately and examined under the phase contrast microscope: 50 colonies whose cells were $\mathrm{Whi}^{+}$were recovered. Cells from these colonies were inoculated into YEPD and grown to stationary phase and their phenotype re-examined. Cultures with a good wild-type phenotype were diluted and plated on YEPD to allow approximately 100 colonies to grow per plate. These were replicated onto plates without leucine. Colonies which failed to grow had presumably segregated out the plasmid, and if the $\mathrm{Whi}^{+}$phenotype was due to a sequence carried by the plasmid then the $\mathrm{Leu}^{-}$colonies should now also have been $\mathrm{Whi}^{-}$. Of the original 50 isolates, 10 showed the required behaviour. Plasmid DNA was extracted from these and used to transform $E$. coli $\mathrm{Hb} 101$ cells to Ampr. The plasmids were recovered from the bacteria, a restriction map prepared of each, and Iso 34 (see previous section) yeast cells transformed to $\mathrm{Leu}^{+}$with each. Only one plasmid was recovered that contained an insert. This plasmid, which we called pSG1, when used to transform Iso 34 caused all the $\mathrm{Leu}^{+}$transformants to be Whi ${ }^{+}$based on microscopic examination (Fig. 1) and cell size measurements (Fig. 2). The vector pJDB207 had no effect on cell phenotype (Figs 1 and 2).

No attempt was made to investigate the failure to recover plasmids carrying an insert from the other nine clones which gave the required co-segregation pattern. The failure could have been due either to recombination with the resident $2 \mu \mathrm{m}$ plasmid giving rise to deletions and rearrangements, or to co-transformation having occurred originally with a vector lacking an insert and enjoying a competitive advantage in subsequent replication. In view of the recovery of the original vector from $\mathrm{Whi}^{+}$transformants it is important to note that pJDB207 alone consistently failed to affect the $\mathrm{Whi}^{-}$phenotype of Iso 34 . 

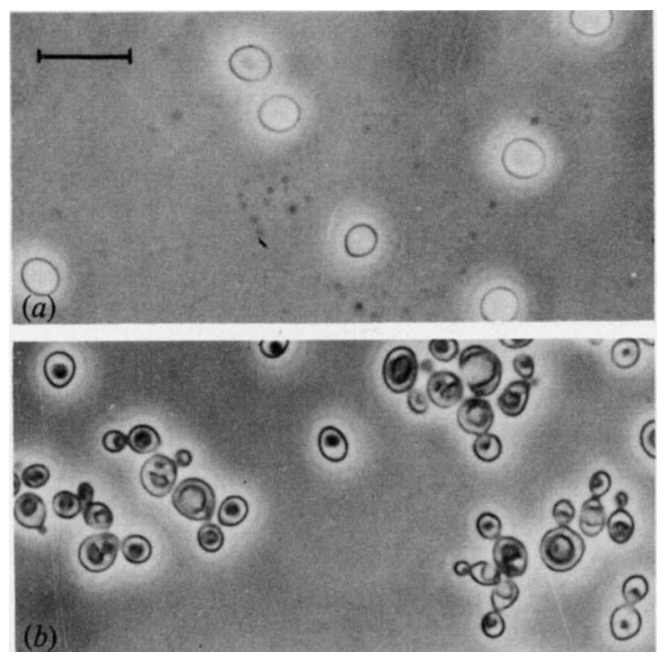

Fig. 1. Phase contrast micrographs of Iso 34 cells transformed with (a) pSG1 or $(b)$ pJDB207. Transformed cultures were grown so as to allow expression of the whi2 phenotype as described in Methods. Bar, $10 \mu \mathrm{m}$.

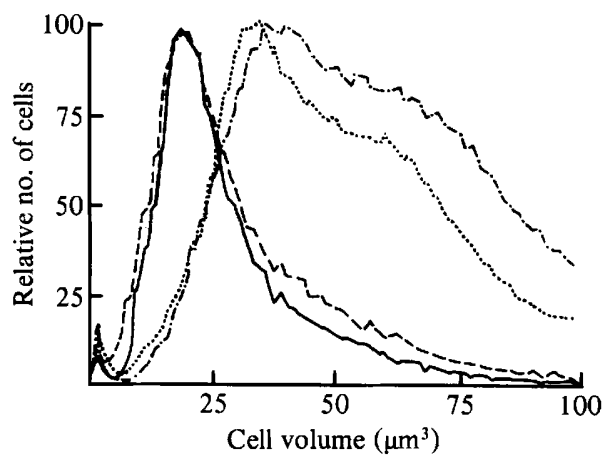

Fig. 2. Distribution of volumes of transformed cells of Iso 34. Transformed cultures were grown to stationary phase so as to allow expression of the whi 2 phenotype as described in Methods, and cell volume distribution determined with a Coulter counter and channelyser. - - Iso 34 : :pJDB207; --- , Iso $34:$ :pSG2; $\cdots \cdots$, Iso $34::$ pSG $1 ;-\cdot-\cdot-\cdot$, Iso $34::$ pSG3.

Subclones derived from pSG1 are shown in Fig. 3 and the relationship of the insert carried by the subclones to the original clone is indicated in Fig. 7. The original $5.4 \mathrm{~kb}$ fragment is subcloned in pJDB207 in pSG2 and pSG3. When Iso 34 cells were transformed with pSG2 and pSG3, pSG3 was found to fully suppress whi2 but pSG2 had no effect (Fig. 2). It should be noted, however, that pSG2 has the insert in the opposite orientation to its orientation in pSG1, so that it remains possible that it would contain complementing activity if it were cloned in the same orientation. Transformation frequencies with pSG1, pSG2 and pSG3 were equal, resulting in $10^{3}$ transformants $(\mu \mathrm{g} \text { DNA })^{-1}$. Stability was also similar: $1 \%$ of cells were $\mathrm{Leu}^{-}$after 10 generations of growth on YEPD.

Plasmid pSG4 is an integrating plasmid which lacks the $2 \mu \mathrm{m}$ origin of replication. Plasmid pSG6 was constructed as a hybridization probe in which the insert carried by pSG3 was subcloned into pAT153 (Twigg \& Sherratt, 1980) and which carries no other yeast derived sequence.

\section{Verification that pSG3 carries the WHI2 structural gene}

To determine whether pSG3 carries the WHI2 structural gene or an extragenic suppressor, attempts were made to integrate the sequence and determine whether the site of integration 

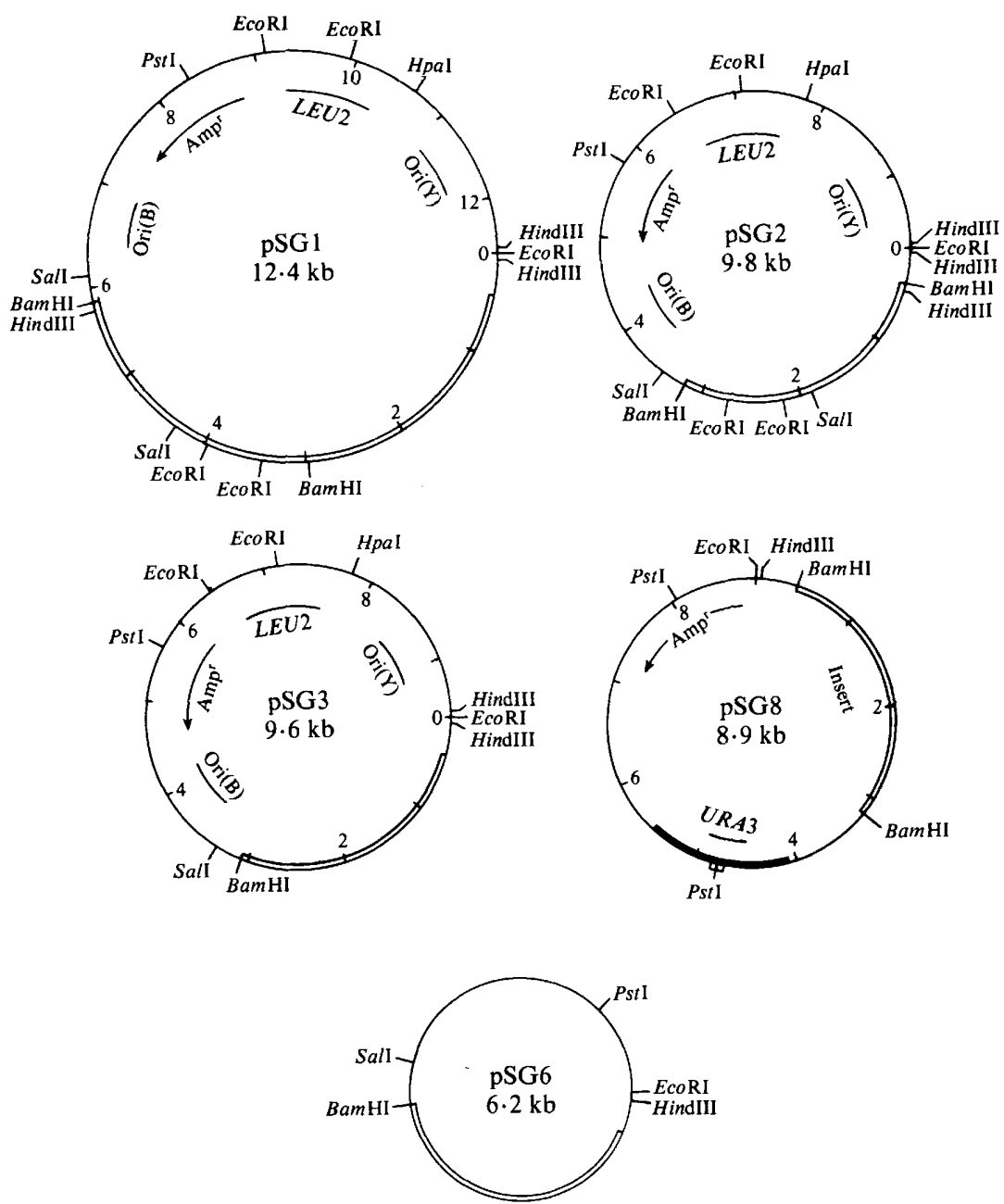

Fig. 3. Recombinant DNA plasmids: pSG1, pSG2, pSG3, pSG6 and pSG8. Open boxes represent the yeast nuclear DNA insert. Ori(Y), origin of replication in yeast $(2 \mu \mathrm{m}$ plasmid origin); Ori(B), origin of replication in bacteria (pBR322 origin). pBR322 derived sequences extend from the EcoRI site at position 0 to the EcoRI site between the Ampr gene and the LEU2 gene.

mapped to the $W H I 2$ locus. The $2.6 \mathrm{~kb}$ insert in pSG3 contained no restriction sites for 13 restriction enzymes tested which have a hexanucleotide target sequence. This prevented the normal technique of directed integration following cleavage at a unique restriction site (OrrWeaver et al., 1981, 1983). Instead an integrating plasmid, pSG4, was derived from pSG3 by deleting the yeast origin of replication as described above.

X4003-5B and Iso 34 yeast cells were transformed to $\mathrm{Leu}^{+}$with pSG4. It was hoped that $\mathrm{Leu}^{+}$ colonies would arise by integration of pSG4 in sites homologous to either the LEU2 gene or the cloned insert. In fact our experiments showed that 33 out of 67 of the $\mathrm{Leu}^{+}$colonies arose by a second site suppressor mutation which simultaneously suppressed the his 4 allele carried by $\mathrm{X} 4003-5 \mathrm{~B}$ and Iso 34 ; of the remaining 34 only three contained vector sequences when examined by hybridization, and in two of these multiple insertion $(>50)$ had occurred; in all three the integration had taken place at the $L E U 2$ locus.

By deleting the origin of replication from pSG3, 245 base pairs derived from the $2 \mu \mathrm{m}$ plasmid were left in pSG4. Where pSG4 sequences were retained in our experiments genetic data (not shown) excluded recombination with the resident plasmid. The difficulty may have been caused 
Table 1. Linkage relationship between the site of integration of pSG8 and the WHI2 locus

\begin{tabular}{|c|c|c|c|c|c|}
\hline Strains crossed & Genotypes* & $\begin{array}{c}\text { Parental } \\
\text { ditypes }\end{array}$ & $\begin{array}{c}\text { Non- } \\
\text { parental } \\
\text { ditypes }\end{array}$ & Tetratypes & $\begin{array}{c}\text { Map } \\
\text { distanc } \\
\text { (cM) }\end{array}$ \\
\hline $\begin{array}{l}\text { X4003-5B : :pSG8-14 } \\
\text { X4003-5B : :pSG8-1-1b }\end{array}$ & $\begin{array}{l}\text { ura3 URA3 WHI2 } \\
\text { ura3 whi2 }\end{array}$ & 12 & 0 & 0 & $<3.8$ \\
\hline $\begin{array}{l}\mathrm{X} 4003-5 \mathrm{~B}: \text { :pSG8-16 } \\
\text { Iso } 38\end{array}$ & $\begin{array}{l}\text { ura3 URA3 WHI2 } \\
\text { ura3 whi2 }\end{array}$ & 15 & 0 & 1 & $3 \cdot 3$ \\
\hline \multirow[t]{2}{*}{$\begin{array}{l}\text { X4003-5B : :pSG8-1 } \\
\text { Iso } 38\end{array}$} & $\begin{array}{l}\text { ura3 URA3 WHI2 } \\
\text { ura3 whi2 }\end{array}$ & 5 & 0 & 0 & $<8.3$ \\
\hline & & Total 32 & 0 & 1 & $1 \cdot 5$ \\
\hline
\end{tabular}

* Full genotypes of X4003-5B and Iso 38 are given in Methods. The URA3 locus was present on pSG8.

by the LEU2 sequence of pJDB219 (Beggs, 1981). Dobson et al. (1981) have shown that this sequence may contain a small repetitive RNA gene. Furthermore, Orr-Weaver et al. (1983) have reported difficulties in obtaining single copy integrants using the $L E U 2$ gene. Lastly, it is possible that the $W H I 2$ gene itself is responsible for the difficulty.

A new strategy was adopted which avoided these problems. Hybridization experiments (see below) demonstrated that the sequence carried by pSG2 does lie adjacent to the putative $W H I 2$ gene. Restriction sites are available in this sequence so that directed integration would be possible. The BamHI fragment containing yeast chromosomal DNA was subcloned into the BamHI site of YIp5 (Struhl et al., 1979) to produce pSG8 (Fig. 3). No unique sites had been identified in the inserted sequence, so in order to generate molecules cleaved only in this sequence pSG8 was partially digested with EcoRI. S. cerevisiae strain X4003-5B was transformed with the products and $\mathrm{Ura}^{+}$transformants were recovered at a rate of $10^{2}$ transformants ( $\mu \mathrm{g} \mathrm{DNA})^{-1}$. To test whether the site of integration is closely linked to the $W H I 2$ locus, which has not so far been genetically mapped, $\mathrm{WHI}^{+} U \mathrm{RA} 3$ transformants were crossed to ura 3 whi 2 strains. If the insert in $\mathrm{pSG} 8$ derives from a chromosomal sequence adjacent to the $W H I 2$ locus then $U R A 3^{+}$and $W H I 2^{+}$should be tightly linked. Crosses described in Table 1 were made to discover if this was the case. Three separate integrants were used to confirm that integration did not occur at more than one locus. In all three crosses $U R A 3$ was closely linked to WHI2 so we conclude that, in these crosses at least, integration was probably occurring at a unique locus. Since the same map interval was being measured the data may be combined to give an overall map distance of $1.5 \mathrm{cM}$. The $U R A 3$ sequence is separated from the $W H I 2$ gene by at least $2.8 \mathrm{~kb}$ (Fig. 7) of homologous DNA, the observed recombination frequency is thus consistent with previous estimates of $1.5-3.0 \mathrm{~kb} \mathrm{cM}^{-1}$ correlating physical and genetic distances (Mortimer \& Schild, 1981).

Because we had not integrated the WHI2 gene itself and because of the failure of pSG4 to integrate efficiently we did further hybridization experiments to confirm firstly that the plasmid sequence was now being integrated, and secondly that the site of integration was indeed adjacent to the chromosomal location of the insert carried in pSG3. DNA was isolated, by the 'rapid' method, from two of the transformants, X4003-5B : :pSG8-1 and X4003-5B : :pSG8-14, together with DNA from the parent X4003-5B strain. After digestion with Pst I the DNA was hybridized to pSG6 in a Southern transfer experiment. The result is shown in Fig. 4. The single $7 \cdot 2 \mathrm{~kb}$ fragment from X4003-5B which hybridizes to pSG6 had disappeared in DNA prepared from the transformants but additional bands were present. A map derived from these results is shown in Fig. 7. X4003-5B ::pSG8-14 has clearly one copy of pSG8 integrated at a site immediately adjacent to the chromosomal location of the sequence carried by pSG6 (and pSG3). X 4003-5B : :pSG8-1 has multiple copies (approximately 3) of pSG8 in a tandem array immediately adjacent to the same site. When this experiment was repeated with pBR322 as the hybridization probe an identical result was obtained except that, as expected, no hybridization was observed against X4003-5B DNA. 


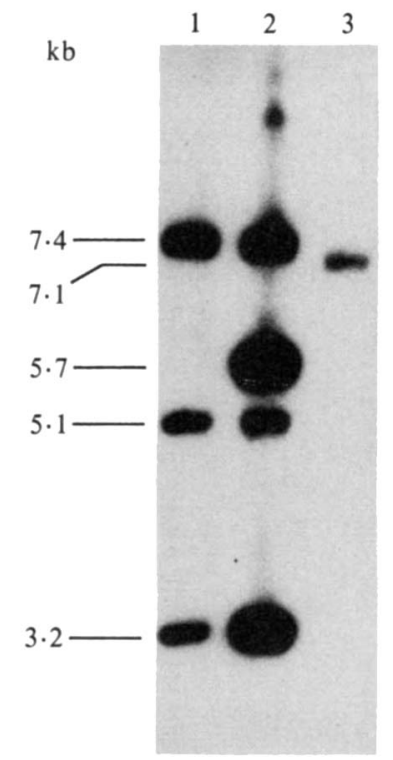

Fig. 4. Autoradiograph of Pst I cleaved chromosomal DNA from X4003-5B : :pSG8-1 (lane 1), X4003SB : :pSG8-14 (lane 2) and X4003-5B (lane 3) hybridized against ${ }^{32}$ P-labelled pSG6.

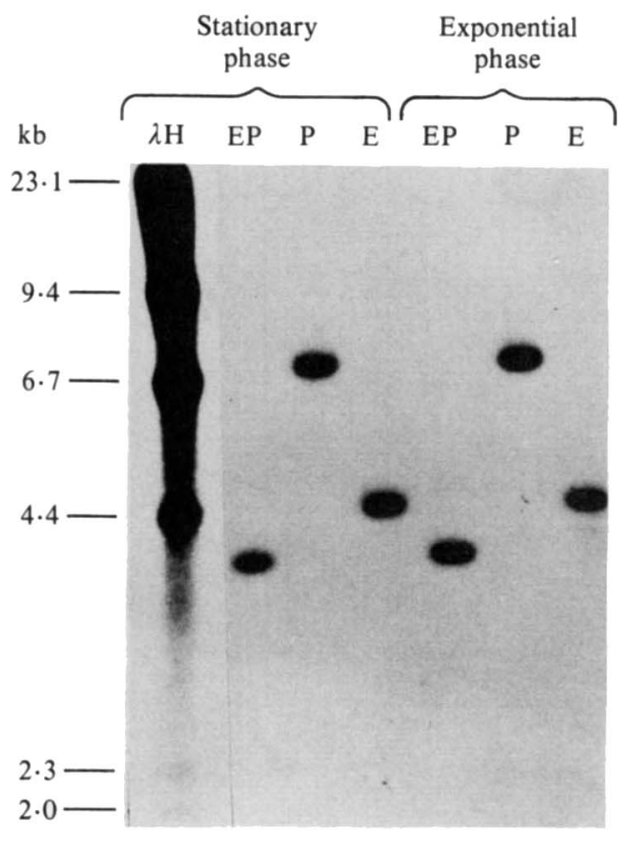

Fig. 5

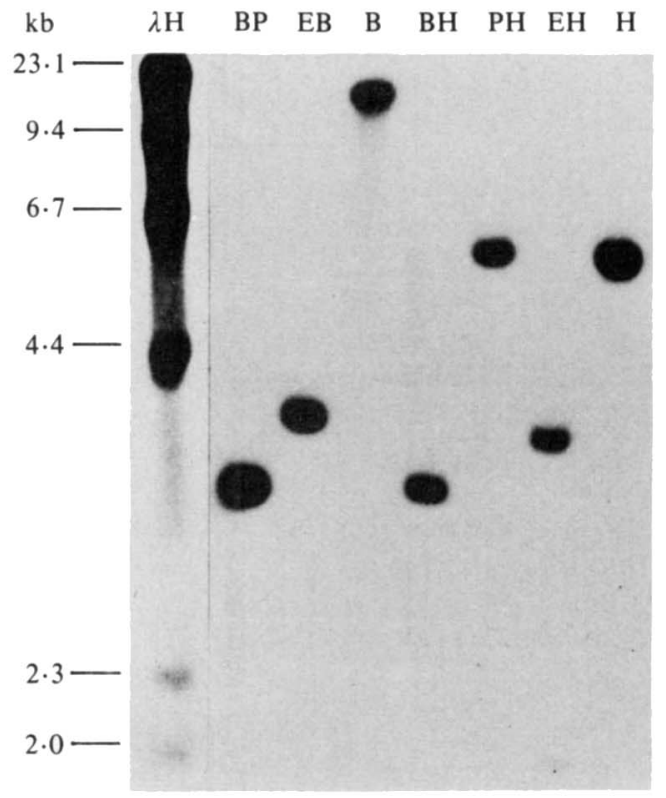

Fig. 6

Fig. 5. Autoradiographs of restriction endonuclease cleaved chromosomal DNA from exponential phase and stationary phase cultures of X4003-5B and Iso 34 hybridized against ${ }^{32}$ P-labelled pSG6. E, EcoRI; P, PstI; H, HindIII.

Fig. 6. Autoradiographs of restriction endonuclease cleaved chromosomal DNA from exponential phase cultures of X4003-5B and hybridized against ${ }^{32} \mathrm{P}$ labelled pSG6. E, EcoRI; P, Pst I; H, HindIII; B, BamHI. 


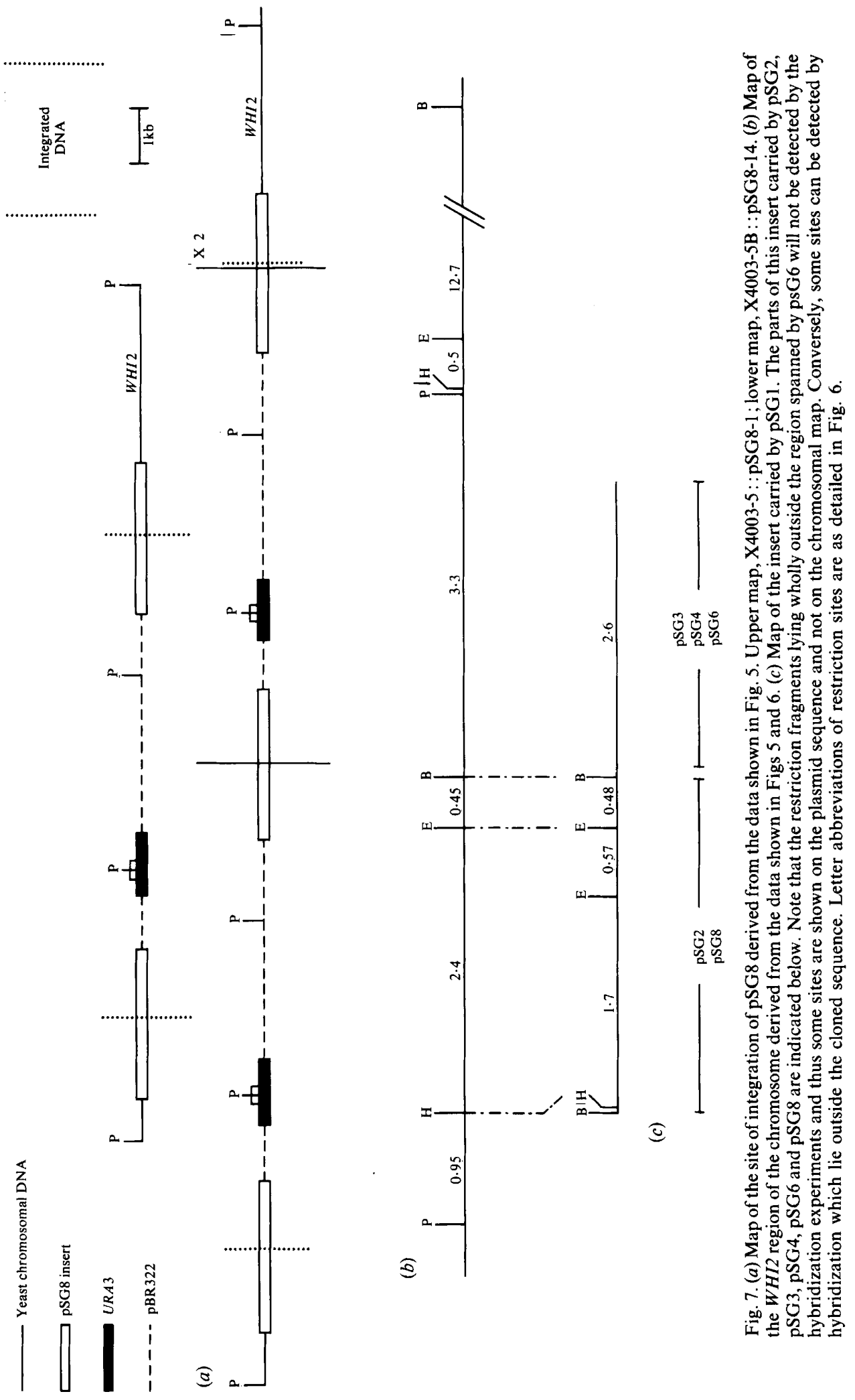




\section{Chromosomal structure of the WHI2 locus}

Control of mating type in $S$. cerevisiae involves DNA transposition events (for a review see Nasmyth et al., 1981). It is possible that the transition from the proliferative to the nonproliferative state as nutrients are exhausted involves a similar mechanism of transposition. Since the WHI2 locus is concerned with the regulation of this transition it was of interest to discover whether the $W H I 2$ gene changed its chromosomal location as cells entered stationary phase. DNA was isolated from exponentially growing $W H I 2^{+}$and whi2 cells and also from stationary phase $\mathrm{WHI}^{+}$and whi 2 cells. The four types of DNA were digested with EcoRI and $P$ st I separately, and also EcoRI and PstI in a double digest, and hybridized against pSG6 in a Southern transfer experiment. The results for DNA isolated from $\mathrm{WHI}^{+}$cells are given in Fig. 5 ; identical results were obtained for whi2 DNAs (not shown). There was clearly no gross change in chromosomal structure detectable in this experiment. A more complete map of chromosomal structure was obtained by digestion with different restriction enzymes followed by hybridization against pSG6. The result for $W H I 2^{+}$DNA from exponentially growing cells is shown in Fig. 6 (an identical result was obtained with whi2 DNA, showing that the whi2 mutation is not a large deletion or rearrangement). Fig. 7 shows a chromosomal restriction map derived from 5 and 6 together with maps of the insert carried by pSG1, pSG2, pSG3, pSG4, pSG6, and a map of the chromosome following pSG8 integration derived from the results shown in Fig. 5. Fig. 7 shows that pSG1 carries a continuous sequence of chromosomal DNA and has not arisen through coligation of independent BamHI fragments during the construction of the gene library.

We have thus shown the following.

(a) By hybridization, that the inserts in pSG2 and pSG3 lie immediately adjacent to each other on the chromosome.

(b) That pSG3 completely suppresses the whi 2 mutation.

(c) That when the insert in pSG2 is integrated (via pSG8) it does so immediately adjacent to the site of the insert in pSG3.

(d) That when pSG8 is integrated its $U R A 3$ gene maps $1.5 \mathrm{cM}$ away from the $W H I 2$ gene. The $U R A 3$ gene is separated from the putative $W H I 2$ gene by at least $2.8 \mathrm{~kb}$. Current estimates are that $1 \mathrm{cM}=1.5-3.0 \mathrm{~kb}$.

We conclude from the above that pSG3 carries the $W H I 2$ structural gene.

This work was supported by a grant from the Science and Engineering Research Council. D. J. Saul was also in receipt of a Research Training Award from the Science and Engineering Research Council. We are grateful for advice from A. R. Goodey and we also wish to acknowledge the help we received from the course in Basic Cloning Techniques held at Leicester University. We also thank J. Trevethick and G. S. Ortori for technical assistance.

\section{REFERENCES}

BeGGS, J. D. (1978). Transformation of yeast by a replicating hybrid plasmid. Nature, London 275 , 104108.

BEGGS, J. D. (1981). Gene cloning in yeast. In Genetic Engineering, pp. 175-203. Edited by W. Williamson. London: Academic Press.

BIRnBoIM, H. C. \& Doly, J. (1979). A rapid alkaline extraction procedure for screening recombinant plasmid DNA. Nucleic Acids Research 7, 1513-1523.

BROACH, J. R. (1981). The yeast plasmid $2 \mu \mathrm{m}$ circle. In The Molecular Biology of the Yeast Saccharomyces. Life Cycle and Inheritance, pp. 445-470. Edited by J. N. Strathern, E. W. Jones \& J. R. Broach. New York: Cold Spring Harbor Laboratory.

Dawes, I. W. \& HARDIE, I. H. (1974). Selective killing of vegetative cells in sporulated yeast cultures by exposure to diethyl ether. Molecular and General Genetics 80, 281-289.
Deutch, C. E. \& Parry, J. M. (1974). Sphaeroplast formation in yeast during the transition from exponential phase to stationary phase. Journal of General Microbiology 80, 259-268.

Dobson, M. J., Kingsman, S. M. \& Kingsman, A. J. (1981). Sequence variation in the LEU2 region of Saccharomyces cerevisiae genome. Gene 16, 133139.

HARTWELL, L. H. (1974). Saccharomyces cerevisiae cell cycle. Bacteriological Reviews 38, 164-198.

Hicks, J. B. (1982). Cloning by complementation in yeast : the mating type genes. In Genetic Engineering, vol. 2, pp. 219-248. Edited by J. K. Setlow \& A. Hollaender. New York: Plenum Press.

Johnston, G. C., Ehrhardt, C. W., Lorincz, A. \& CarTer, B. L. A. (1979). Regulation of cell size in the yeast Saccharomyces cerevisiae. Journal of Bacteriology 137, 1-5. 
Lederberg, E. M. \& Cohen, S. N. (1974). Transformation of Salmonella typhimurium by plasmid deoxyribonucleic acid. Journal of Bacteriology 119, 10721074.

Lillie, S. H. \& Pringle, J. R. (1980). Reserve carbohydrate metabolism in Saccharomyces cerevisiae: responses to nutrient limitation. Journal of Bacteriology 143, 1384-1394.

LORINCZ, A. \& CARTER, B. L. A. (1979). Control of cell size at bud initiation in Saccharomyces cerevisiae. Journal of General Microbiology 113, 287-296.

Maniatis, T., Fritsch, E. F. \& SAMbrooK, J. (1982). Molecular Cloning: A Laboratory Manual. New York: Cold Spring Harbor Laboratory.

MORTIMER, R. K. \& SCHILD, D. (1981). Genetic mapping in Saccharomyces cerevisiae. In The Molecular Biology of the Yeast Saccharomyces. Life Cycle and Inheritance, pp. 11-26. Edited by J. N. Strathern, E. W. Jones \& J. R. Broach. New York: Cold Spring Harbor Laboratory.

Nasmyth, K. A., TAtchell, K., Hall, B. D., Astell, C. \& SMITH, M. (1981). A physical analysis of mating type loci in Saccharomyces cerevisiae. Cold Spring Harbor Symposia on Quantitative Biology 45, 961975.

OrR-Weaver, T. L., Szostak, J. W. \& Rothstein, R. J. (1981). Yeast transformation: a model system for the study of recombination. Proceedings of the National Academy of Sciences of the United States of America 78, 6354-6358.

OrR-Weaver, T. L., Szostak, J. W. \& Rothstein, R. J. (1983). Genetic applications of yeast transformation with linear and gapped plasmids. Methods in Enzymology 101, 228-245.

Parry, J. M., Davies, P. J. \& Evans, W. E. (1976). The effect of "cell age" upon the lethal effects of physical and chemical mutagens in yeast. Molecular and General Genetics 146, 27-35.

Saul, D. J., Walton, E. F., Sudbury, P. E. \& CARTER, B. L. A. (1985). Saccharomyces cerevisiae whi2 mutants in stationary phase retain the properties of exponentially growing cells. Journal of General Microbiology 131 (in the Press).

Schenberg-Frascino, A. \& Moustacchi, E. (1972). Lethal and mutagenic effects of elevated temperature on haploid yeast. 1. Variations in sensitivity during the cell cycle. Molecular and General Genetics 115, 243-257.

Sherman, F., Fink, G. R. \& LaWrence, G. W. (1974). Methods in Yeast Genetics. New York: Cold Spring Harbor Laboratory.

SNow, R. (1966). An enrichment method for auxotrophic yeast mutants using "Nystatin". Nature, London 211, 206-207.

SoUTHERN, E. (1975). Detection of specific sequences among DNA fragments separated by gene electrophoresis. Journal of Molecular Biology 98, 503-517. Struhl, K., StinchComb, D. T., Scherer, S. \& Davis, R. W. (1979). High frequency transformation in yeast: autonomous replication of hybrid DNA molecules. Proceedings of the National Academy of Sciences of the United States of America 76, 10351039.

Sudbery, P. E., Goodey, A. R. \& Carter, B. L. A. (1980). Genes which control cell proliferation in the yeast Saccharomyces cerevisiae. Nature, London $\mathbf{2 8 8}$, 401-404.

Twigg, A. J. \& SherratT, D. (1980). Trans-complementable copy-number mutants of plasmid ColE1. Nature, London 283, 216-218. 